\title{
The Influence of Environmental Quality Standards and Safety Standards on Spatial Planning
}

\author{
Water and air as examples
}

\author{
Toon De Gier, Frank Groothuijse, Marleen van Rijswick and Jan Robbe*
}

\section{Introduction}

Over the last few years, European water policy has been faced with a considerable amount of changes and innovations. Important causes of this are in the first place changing natural circumstances, such as for instance climate change. Secondly, the policy perspective has changed: the concept of 'integrated water system management' has been introduced. This means that waler policy, more so than was the case before, is geared towards all aspects of the water system in their mutual connection: surface water, ground water, banks, flora and faunia, dians and the technical infrastructure. The ecology is beginning to play an ever more significant role. For

* The authors are all affiliated with the Centre for Environmental I. aw and HolicyiNII OS of the Utrecht Lniversity School of I aw

1 Directive 2000/60: 1 C of the Huropean Parliament and of the Council of 23 October 2000 establishing a framework for Community action in the field of water policy, of $20001327 / 7$.

2 Id.

3 Proposal for a Directive of the European Palliament and of the Council on the assessment and management of floods, 18.1.2006,2006/0005 (COD), SEC (2006)06. The proposal for a Marine Strategy Framework Directive is not considered here.

4 No EC legis ation has been established in the field of spatial planning. That is not to say, however, that the impact of $E C$ environmental directives on the spatial planning of the Member States is not substantial. Well-known examples may be found in the case-law concerning the Environmental Impact Assessment Directive (Council Directive $85 / 337 /$ EEC of 27 June 1985 on the assessment of the effects of certain public and private projects on the environment, OJ $L$ 175), the Birds Directive (Council Directive $79 / 407 / \mathrm{EEC}$ of 2 April 1979 on the conservation of wild birds, OJ $L 103$ ) and the Habitats Directive (Council Directive $92 / 43 / E E C$ of 21 May 1992 on the conservation of natural habitats and of wild flora and fauna, OJ L 206. See also: Backes' Freriks/Nijmeijer, Article 6 habitats Directive, A comparative law study on the implementation of art. 6 labitats Directive in somc member states, Utrecht University, Centre for Environmental Law and Policy/NILOS, 2006) and the Air Quality Directives (Directive 1996/62/EC (Air Quality Framework Directive) and Directive 1999/30/EC (Air Quality Daughter Directive). See more in general concerning external integration: Dhondt, Integration of Environmental Protection into other FC. Policies, Furopa law Publishing 2003. this reason, water quality and water quantity are also more often considered as mutually connected concepts. Thirdly, policy-making structures have become more complex. With the introduction of the concept of 'integrated water system manage ment' the interdependencies between the policy sectors of environmental management or water management and spatial planning have come more prominently to the fore. The Europearn Water Framework Directive ${ }^{1}$ - dealing with the Furopean handling of especially the issue of water quality - has added an international dimension to the originally mational approach.

The changes in Furopean water policy also have implications for water policy and water law at national level. This concerns the implementation of the Water Frarnework Directive ${ }^{2}$ and in time also the Flood Risk Management Directive. ${ }^{3}$ These Directives give rise to various issues in connection with the national implementation. An important question is what role the cmvirommental quality and safety standards as required by the Water Framework Direclive and the Flood Risk Management Directive should play in other policy areas, amongst others, in the field of spatial planning. In the field of water mamagement there is usually also legislaLion at the level of the Member States which has not resulted from European directives. This is certainly the case for the low-lying delta country of the Netherlands. The Water Framework Directive has opted for a Lerrilorial approach based on river basins. By opting for an ecological approach resulting in ecological quality objectives it may be expected that water management will increasingly influence spaLial planning in the Member States. The question thereby arises to what extent the quality standards that are part of the mandatory 'good status' under the Water Framework Iirective should be given eflect in the decision making in the field of spatial 
planning in the Member States so as to be able to eventually, in 2015, fulfil the obligations under the Directive. Over the next few years, this issue will be tabled in more Member States. At present, the reli tionship between water management and spatial planning plays an important role in the discussion in the Netherlands. ${ }^{5}$ This is partly caused by how the Netherlands has transposed the quality stan dards as regards air into national law. The manner of transposal that was chosen in the Netherlands has had the effect of causing considerable delay to many building projects and the laying of roads or caused plans for this to be changed or halted." Presently, there is a fear that the water quality standards from the Water Framework Directive will have the same stagnating effect on economic development.

The same questions that arise over water quality standards will also - albeit it less so - play a role in water safety policy, especially in flood risk management. At this mornent, a directive on flood risk man agement is being prepared. ${ }^{7}$ In the protection against floods and flooding standards will also play an important part. One difference is that these standards are not established at European level. The standards for salety and flooding are established by the Member States themselves based on their national legislation and suited to the situation of each separate Mermber State. Nevertheless, these standards too will have a major impact on spatial planning.

In this contribution, we will outline the possibilities under Dutch law for allowing environmental quality requirements and safety standards against floods and flooding influence the decision making in the framework of spatial planning. Our starting point will be new legislation that is currently being prepared for water management and spatial planning. In some places, attention will be paid to the way in which this is done in other Member States. The research is not, however, of a comparative law nature. After this introduction, the requirements following from the Water Frarricwork Directive are briefly outlined (section II.) and the way in which the Directive is transposed into Dutch law (section III.). Subsequently, a more general outline is given of the ways in which quality requirements can impact on other policy areas (section IV.). In section IV.1. the manner of impacting is described as it is provided for under the new water legislation, while section IV.2. discusses the mamner of impacting under current law. In section V. the pos- sibilities that exist for lelting quality requirements have an effect on spatial planning are further examined, whereby attention is first paid to the planning and legal framework (section V.1.). In section V.2. it is described how Dutch air quality standards impact on spatial planning. Section V.3. gives a general picture of how quality requirements and safety standards against floods and flooding can have an effect on spatial planning. This is further elaborat ed in section V.4. for the water quality standards and in section $V .5$. for the water quantity standards. This contribution does not contain a separate sec tion on the Flood Risk Management Directive. Section VI. provides the conclusion to the search for the optimal impact of quality standards and safety standards on spatial planning. Section VII. contains some concluding remarks.

5 In this context a study has been carried out which was commis sioned by the national Environment and Sature Planning bureau into the external integration between water management and spatial planning: van Rijswick/Driessen/Backes/Dieperink/ de Gier/Groothuijse, Juridisch-bestuurlijke capaciteit in het waterbeleid, enkele toekomstschetsen voor de externe integratie van water en ruimtelijke ordening, Centre for Environmental $l$ aw and Folicy/NILOS, Utrecht, 2006. The outcome of this research has been used in this article.

6 See Fleurke/Koeman, The impad of the Ell Air Quality Standards on the planning and authorisation of large scale infrastructure projects in the Netherlands', JEEPL 2005, pp. 375-383. See also: Eackes e.a., Transformation of the first Daughter Directive on air qualicy in several EU Mermber States and its application in practice, European Environmental Law Review', Junc 2005 , Pp. $157-164$

7 Directive on the assessment and management of floods COM(2006) 15, See Breuer, 'Der Vorslag für eine $f(i-H o c h w a s-$ serrichtlinie - eine kritische Würdiging', EurLP 2006 , pp. 170-177; Rother 'Beitrag zur Diskussion um den Entwerf einer europäischen Hochwasserschutzrichtlinie - aus technischer Sicht', FurUP 2006, pp. 178-183 and see also: loint Approach for Managing Flooding (JAF), which was a 5 -year project in cooperation with German, English and Dutch organization to find innovative measures to temporarily store water in the case of heavy rainfall in the area where the precipitation occurred in the framework of the Interreg III-programme (a programme of the European Commission with the aim of promotion the exchange of knowledge and area-oriented cooperation between various parties in different countries).

8 Lavrysen/Michiels (eds.), Milieurecht in de Lage Landen, Rechtsvergelijkende studies over de milieuvergunning, emissiehandel, de watertoets, natuurbescherming en bestuurlijke handhaving in Vlanderen en Nederland, Boom juridische uitgevers, Den Haag 2004, pp. 203-213; Maes/Lavrysen (eds.), Integraal waterbeleid in Vlaanderen en Nederland, pp. 265-297, Die Keure, Brugge, 2003: Bohne (ed.) Tagungsband, Ansätze zur Kodification des LImweltrechts in der Europäschen Union: Die Wasserrahmenrichtlinie und ihre Umsetzung in Nationales Recht', Schriftenreihe der Hochschule Speyer, Band 169. Berlin 2005; Neuray (cd.), La directive 2000/60/CE du 23 octobre 2000 établissant un cadre pour une politicue communautaire dans le domaine de léau, Iroit européen, Droit interne-Droit compare, Bruyant, Bruxelles 2005 ; van Rijswick (ed), The Waterframework Directive, Implementation into German and Dutch I aw, C.H PjNII OS, Utrecht 2003. 
In our search for the oplimal harmonization of water management and spatial planning it has amongst other things been examined which means of external harmonization between environmental quality requirements and spatial planning have been used in different Member States with respect. to air quality standards. ${ }^{9}$ In this field, after all, there is already some experience, while the shap ing of the relationship between the quality standards from the Water Framework Directive and the standards for flood risks and flooding on the one hand and the impact of these standards on spatial planning on the other hand is a new field within European environmental law. With a description of the Dutch search for the relationship between the requirements from water management and spatial planning we hope to initiate the discussion on the proper application and functioning of the instrument of the (European) quality requirement in spatial planning. Now that the legislation concerned in spatial plaming is purcly domestic, we cannol escape from giving a briel description of this Dutch legislation. Thereby we will take as our starting point the new Dutch legislation in the field of spatial administrative law. In the years to come - and following the example of a number of other European Member States Dutch water legislation will also be thoroughly reformed. ${ }^{10}$ Eight existing water laws will be com bined into an inlegrated Waler AcL. The proposal for the Water $\Lambda$ ct was submitted to Parliament on 28 September 2006." Ihis new Water Act forms the starting point of our research.

9 Backes e.a., 'Transformation of the first Daughter Directive on air quality in several EU Member States and its application in practice', European Environmental Law Review, June 2005, pp. 157-161

10 See De Heer' \ijwening/De Vuys/Snil/Groenendijk/van Rijswick, Jowards Integrated Water Legislation in the Netherlands, Lessons from other countries. Ministerie van Verkeer en Waterstaa/RIZA, The Hague 2004; De Heer/Nijwening/ De Vuyst/Smit/Groenendijk/van Rijswick, Towards Integrated Water Legislation, Lessons from other countries, Case study reports, Ministerie van Verkeer en Waterstaat/RIZA, The Hague 2004.

11 Kamerstukken II, 2006-2007, 30818, Vos. 7-4, Regels met betrekking tot het beheer en gebruik van watersystemen Waterwei).

12 This mearns that for exanple also the Soil Diredive (COM(2006) final, 2006,0086 COD) which is currently being prepared will be relexant for water management.

\section{The Water Framework Directive}

The Water Framework Directive intends to create an integrated approach to water policy, which is based on an (international) river basin approach. Coastal waters are also considered part of the river basins. To this end, the Netherlands has been divid od into four river basin districts (Rhine, Meuse, Scheldt and Fems). This means that there is close cooperation with Germany, Belgium, Luxemburg and France as $\mathrm{EC}$ Member States and where possible also with Switzerland.

For every river basin distric $L$ a river basin management plan has to be established, with a programme of measures in order to meet the requirements under the Directive. The objective of the Framework Directive is to achieve the 'good status' of all Furopean walers. This is true for both groundwater and surface waters. In addition, the Directive aims to prevent the consequences of major droughts and floods. The Directive, as a result of the objective of 'good status' which can only be achieved if the measures also concern the area that drains into the rivers, necessarily establishes a close connection between policy and the measures which have to be taken on the basis of water policy, environmental policy (including soil policy), ${ }^{12}$ nature conservation policy and the policy for spatial planning. 'Policy integration' is an important focal point. This policy integration is necessary in the entire European Community.

\section{Environmental objectives}

The objectives for water quality have been claborated in Article 4 ol the Directive. By 2015 all the water in the Community must have attained 'good status'. The good status of waters is divided into good chemical status and good ecological status.

The good chemical status concerns the amount of priority (among which priority dangerous) substances that are allowed to be present in the water, which mainly concerns priority dangerous substances for which emission limit values and quality standards have been or are established at European level on the basis of older (water) directives. The good chemical status has to be reached for all waters, irrespective of whether they are designated as natural, artificial or heavily modified.

The good ecological status concerns both con centrations of (less) polluting substances (like nutri- 
ents) and the biological and the hydromorphological status of surface waters. The quality standards for the good ecological status are established at the level of the Member State and may differ per (par tial) river basin.

For artificial and heavily modified water bodies good ecological potential has to be reached.

There are a number of possibilities to extend the time-limits for reaching the objectives and to lower the objectives themselves. In this, economic and social considerations may play a role.

In this way the objective of 'good status' may for example be lowered to 'good ecological potential' for artificial and heavily modified water bodies.

The time-limit within which the objectives have to be fulfilled may be divided into stages under certain strict conditions (the Water Framework Di rective provides these conditions in Article 4). For convenience's sake, this contribution will speak of the achievement of good status by 2015 .

The 'good status' from the Water Framework Direstive may be characterixed as a waler quality standard. $^{13} \Lambda$ quality standard from a European law point of view is often regarded as an obligation of result. ${ }^{14}$ Member States have thus bindingly committed themselves to realizing the good status in time, unless the conditions referred to in the Framework Directive to realize lower objectives or to realize objectives at a later date are fulfilled. In addition to the obligations that have to be fulfilled in 2015 , there is a general obligation (based on Article 10 of the $\mathrm{EC}$ Ireaty) not to take any measures or decisions which may seriously jeopardize the achievement of the objectives in $2015 .^{15} \mathrm{U}_{\mathbf{I}}$ less the Member State can justifiably invoke the exceptional provisions referred to in the Directive, the obligation under the Directive is not fulfilled if the required environmental quality is not achieved. In general, the Member States are free to choose the means by which they wish to fulfil the obligations under directives. This all appears to be cut and dried.

IL is not, however. Many questions arise over the instrument of the environmental quality standards, especially in connection with the relationship with other instruments from both European environ mental law and from other FC policy areas, for example agriculture, products, traffic and transport, energy and spatial planning.

In order to achicve good status the Directive pro vides for a large number of instruments, ranging from prohibilions to quality standards, emission limit values, licences, 'other' management measures, plans, financial provisions, etc. Certain instruInents are compulsory under the Water Framework Direclive, others may be used in a supplementary way. The Water Framework Directive offers the Member States more flexibility in the use of differcont instruments than the older water directives and also in the establishment of the national objectives for the good ecological status or the good ecological potential, but by contrast the final objective namely the good status of waters in the European Communily - is a strict requirement.

\section{Dutch implementation of the Water Framework Directive}

The Dutch implementation of the Water Framework Directive took place in 2005 by an amendInent to the Water Management Act [Wet op de waterhuishouding] and the Finvironmental Management Act [Wet milieubeheer]. ${ }^{16}$ It is laid down in the Water Management Act that the Minister of Transport, Public Works and Water Management is the competent authority for all Dutch (parts of) river basins as referred to in the Water Framework Directive. The Act has also been adjusted to the obligation to establish river basin management plans. The river basin management plans for the Rhine, the Meuse, the Eems and the Scheldt are included in the national Water Management Policy Document. Provisions have been added that pro vide for international consultation whereby the obligation to work on cross-border river basin management plans is fulfilled and provision has been made for the implementation of the public participation obligations. The amendments to the Fnvironmental Management Act concern environ-

13 Article 22(1) of the Water Framework Directive, see also van Rijswick, De kwaliteit van water, 2001, p. 69.

14 Van Rijswick, De kwaliteit van water, 2001, p. 54 and $\mathrm{HCJ}$ in Case C-32/05 - Commission v Luxembourg.

15 See Widdershoven, The principle of loyal cooperation, Lawmaking by the European Court of Justice and the Dutch courts', in: Stroinkwan der Linden, Judicial Lawmaking and Administrative Law, Intersentia \& METRO, pp. 3-35.

16 -C. Water Framework Directive Implementation Act, Statsblad 2005,303 . The parliamentary documents dealing with the Implementation Act have been given the number 28808 . See in more detail: van Rijswick, 'The Implemontation of the Watcr Framework Directive in Dutch Law: a Slow but Steady Improvement', JEEPL 2004, pp. 218-227. 
mental qualily standards for the chemical and ecological status of waters, a tightening of the standstill principle and the implementation of the monitoring obligations.

In order to be able to complete the implementation the necessary implementing regulations still need to be adopted. For example, the Orders in Council providing nationwide quality standards for good chemical quality have yel to be established. As to the quality standards for good chemical status it appears obvious that these are established at national level, as the requirements are valid for all waters and as it is important that the requirements have effect on the decision making based on various pieces of legislation.

Good ecological status can be further elaborated in such a way that a differentiation is made into regional or partial river basin levels. In Dutch legislation it is therefore made possible to lay down ecological quality standards in provincial environmental bye laws. Given the compulsory implemen Lation of the ecological objeclives it must be assumed that the provinces are obliged to establish the necessary quality requirements if these are not set at national level.

The lurther implementation ol the planning obligations that follow from the Water Framework Directive are included in the new Water Act which is currently being prepared. The Water Act in prin ciple adopts the system from the Water Framework Directive Implementation $\Lambda$ ct where a (strategic) national water plan is provided for that also includes the four river basin management plans, and a strategic provincial water plan. The national and the provincial water plan are also structural visions as referred to in the Spatial Planning $\Lambda$ ct [Wet op de Ruimtelijke Ordeningl (on which more will be said in section V.1.). In addition the Water

17 See Havekes/Komans/Lazaroms'Pous/Lijerlinde, Waler governance: the Dutch water board model, Dutch Association of Water Boards and the Nederlandse Waterschapsbank N.V which focuses on organizational themes, such as the legal foundation, democratic legitimacy and tax system of the Dutch water boards; Uijterlinderjanssen/Figuères, (ed.), Success Factors in self financing local water management, A contribution to the Third World Water Forum in Japan 2003, Dutch Association of Water Boards, UNESCO. IHE Institute for Water Education, the Nederlandse Waters Chapsbank N.V. and Netherlands Water Partnership 2003.

18 See van Rijswick, 'Implementatie van de Kaderrichtlijn water in het Sederlandse recht', in: Maes $/$ avrysen (eds.), Integraal waterbeleid in Vlaanderen en Noderland, Dic Keurc, Brugge 2003, $p$ p. 278-279.
Acl includes management plans for national waters and for regional waters. The water managers (central government and the water boards) make management plinss.

The mandatory programmes of measures Irom the Water Framework Directive must be sought in 'the most suitable existing plan'. In practice, this means that components of the mandatory pro gramme of measures must be sought in a multitude of plans in various policy areas. The national river basin management plan only offers a summary of the programumes of measures.

The Water Act provides for a licence that concerns all actions in the water system. The way things appear now, the licensing obligation fits in with the requirements that follow from both the Water Framework Directive, the existing European water directives and the Directive currently in preparation concerning flood risk management and the Marine Strategy Framework Directive also in preparation.

As a supplementary instrument, the Water Art provides for the water agreement under which agreements can be concluded concerning water system management. It is as yet unclear whether the resulting format of the water agreement is a suitable instrument for fulfilling the obligations under the Water Framework Directive, or whether it can at least contribute to this.

In the Netherlands, the linancing of water services has for a long time already largely been directly related to those who make use of the water services or who are responsible for possible pollution (the polluter pays). ${ }^{17}$

\section{Effect of environmental standards on other policy areas: general}

There are various possibilities for environmental standards - such as the good status of waters - to have effect on other policy areas and especially on spatial planning. The establishment of environmental or water quality standards whereby it is pro vided that they shall have direct effect on other policy areas is in important instrument. Ilowever, there are various ways in which environmental standards or water quality objectives can be made to impact other policy areas. For example, at prescont use is particularly made of harmonization mechanisms which take place at planning level. ${ }^{18}$ 
To this end there are various harmonization mechanisms, among which the harmonization of forms of planning through the signature of various Ministers, harmonization through the mutual exchange: of inlormation and plans, and through taking into account the policy choices which have been laid down in plans in other policy areas and in addition different provinces use an integrated planning for their entire environmental policy (water, environment, spatial planning, nature). It can be said of all these harmonization mechanisms that they will function properly if governments are prepared to let water quality requirements be part of their decision making in other policy areas, but that at the same time it is relatively easy not to let water management interests be part of the decision making if for whatever reason this is considered opportune. In conclusion, it can be said that harmonization of the planning does not legally guarantee that water quality requirements as they follow from the Water Framework Directive also truly have an effect on the decision making in other policy areas. This is not as black and white when use is made of supervisory mechanisms like approvals and declarations of no objection.

Under the new legislation (bolh the Water Act and the Spatial Planning Act) it has been chosen to apply less steering by means of approval requirements in combination with powers of instruction as a last resort, and instead to opl for the starting point of what is termed 'pro-active steering' by the provinces and central government by means of regulatory powers.

More in general it has to be noted that under Dutch environmental law on the one hand a large role is envisaged for decentralized authorities with a responsibility of their own to achieve the proposed objectives, but that on the other hand this own responsibility has to be exercised within the boundaries set by higher authorities (pro-active steering) and the possibilities which the higher authorities and central government have to inter vene by means of strongly direclional and invasive instruments in order to guarantee that the obligations under the Water Framework Directive can truly be fulfilled (repressive instruments). The choice open $t o$ the decentralized authorities is thus to voluntarily deal with matters themselves in cooperation with other authorities and, if this is not successful, central government or the provincial authorities will intervene.

\section{The effect of water quality requirements on other policy areas: the new legislation}

The draft Water Act only implicitly starts from the premise that the quality standards that follow from the Water Framework Directive and are established on the basis of the Envirommental Management Act are taken into account in all decisions and factual management measures that are taken on the basis of the Water Act. ${ }^{19}$

The way the effect on other policy areas hias been shaped legally dillers per policy area.

For the environmental quality standards based on the Environmental Management $\Lambda$ ct a connection is sought with the system as it stands in $2006 .^{20}$ This means that quality standards are laid down in an Order of Council or in provincial bye-laws and the regulations in question also indicate for which decisions the standards are to be fulfilled. This not only concerns decisions based on water legislation or convironmental legislation, bul also decisions based on laws addressing other policy areas, such as for in stance spatial planning. Now that these quality standards are only expected to be established in 2009, it is not yet possible to indicate for which laws and decisions the water quality standards will be valid.

The effect on spatial planning takes place by also making the water plans on central government level and on provincial level 'structural visions' within the meaning of the Spatial Planning $\Lambda \mathrm{ct}$.

the effect on nature conservation is only regulatod insofar as the quality standards are established on the besis of the Environmental Management Act and the Orders in Council or provincial bye-laws concerned designate decisions based on the Nature Con servation Act 1998 or the Flora and Fauna $\mathrm{Act}^{21 \mathrm{a}}$.

The structure as referred to above in relation to the elfect on nature conservation is also valid for the substances and products policy. ${ }^{21 b}$

19 Kamerstukken II, 2006-2007, 30818, No. 3, p. 94, Memorie van Toelichting, Regels met betrekking tot het beheer en gebruik van watersystemen (Waterwet)

20 Sce Backes/Blomberg/longma/Michiels/van Rijswick, Hoofdlijnen milieubestuursrecht, Boorn juridische uilgevers Den I laag 2004, pp. 119-127 and 194-195.

21a Thesc are the Acts in which the Birds and I labitatsdirective are implenented

$21 b$ Research is currenty being conducted on how in the admission of pesticides and biocides sufticient account can be taken of the environmental quality requirements that are escatolished for water (assessment scheme for water). 


\section{The effect of water quality requirements on other policy areas under current law}

Presently, water qualily standards are already in force on the basis of the Pollution of Surface Waters Act and the Environmental Management Act.

In the Quality objectives and measurements sur face waters Decree ${ }^{22}$ quality standards have been laid down for the required quality for the abstraction of drinking water, the quality of bathing water, the quality of water that has to be fit to support fish lile, and the required quality of shellfish waters. The quality standards are an implementation of obligations from European directives containing quality requirements for waters with a specific function. 23

The obligations to lul [il the quality objeclives are only imposed upon the public authority which, on the basis of the Pollution of Surface Waters Act, is competent to issue permits as referred to under Arlicle 1 of the Pollution of Surface Waters Aci (Article 10 of the Decree). This concerns central gov-

\footnotetext{
22 Stantsblad 1983, No. 606.

23 Council Directive $75 / 440 / E$ EC of 16 June 1975 concerning the quality recuired of surface water intended for the abstraction of drinking water in the Member States, OJ L 194; Council Directive 76/160/EEC of 8 December 1975 concerning the quality of bathing water, recently replaced by Directive $2006 / 7 / E \mathrm{C}$ of the European Parliament and of the Council of 15 February 2006 concerning the management of bathing water quality and repealing Directive $76 / 160 / \mathrm{EEC}$ (see also the corrigendum to Directive 2006/7/EC of the European Parliament and of the Council of 15 February 2006 concerning the management of bathing watcr quality and repealing Directive $76 / 160 / \mathrm{EEC}(\mathrm{O}) \mathrm{L} 64$ of $4 \mathrm{March}$ 2006 i: Council Directive $78 / 659 / \mathrm{EC}$ of 18 July 1978 on the quality of fresh waters needing protection or improvement in order to support fish life; Council Directive $793923 / \mathrm{EFC}$ of 30 October 1979 on the quality required of shellfish waters

21 Council Directive of 15 July 1991 concerning the placing of plant protertion products on the market, OJ 1991 । $375 \% 1$.

25 (ouncil I)irective of 16 february 1996 concerning the placing of biocidal products on the market, $O$ ) $1998 \mathrm{~L} 123$.

26 Whereby the rules call to mind the Air Quality Act that is currently being prepared.

27 ABRvS 1 Warch 2006, No. 200502013:1

28 Statscourant 10 1)erember $2004,247$.

29 In a judgment of 10 May 2001 the Cout of Justice found against the Netherlands (Case $C-152 / 93$ ) because no quality requirements had been established for the Scheldt basin. No quality requirements at all had been established to implement Directivc $76 / 464 / E E C$, but now that the judgment against the Netherlands only conconed the Scheldt basin Regulations were initially enacted for the Stheld basir, published in Stadscourant 2003 , 28, p. 23.

30 Especially Articles $5.1(1), 5.2(1)$ en Article 21.6(6) of the Environriental Maragerrent Act
}

ernment or the water boards. The way in which the requirements have been worded does not clarify whether the values in question are limit values or guide values. Where the Explaniatory Memorandum to the Decree pays atlention to impact on other policy areas the focus is mainly on the relationship with the Water Supply Act (in which the Drinking Water Directive $98 / 83 / \mathrm{LC}$ is implemented) and the Pesticides Act (in which the Plant Protection Products Directive ${ }^{24}$ and the Biocides Directive ${ }^{25}$ are implemented). The relationship with for example the covironment (the Environmental Management Act) or spatial planning (Spatial Planning Act) is not mentioned. ${ }^{26}$

One of the few available examples of the impact of water quality requirements on spatial planning in this case, quality standards that were cstablished in the rramework of the protection of surface waters intended for the abstraction of drinking water - may be found in a decision of the $\mathrm{Ad}$ ministrative Law Division of the Council of State of I March 2006. In the decision it is held that now that an expansion of the area of land used for agriculture is provided under a regional plan (based on the Spatial Planning Act), the adverse consequences for drinking water quality have been insulficiently taken into account. ${ }^{27}$ In the Environmental quality standards dangerous substances surface waters Regulations ${ }^{28}$ the water quality standards are implemented for all Dutch surface waters as these are compulsory under Directive $76 / 464 / \mathrm{EEC}^{29}$ The Regulations are based on the Environmental Management Act. ${ }^{30}$ The Regulations provide in Article $2(2)$ :

'In the exercise of powers that may have consequences for the water quality of surface waters, administrative authorities shall take account of the environmental quality requirements referred to in paragraph 1 and thereby implement the programmes of measures included in Annexes 2 to 5 that are relevant for their jurisdiction.'

The environmental quality standards are considcred als guide values as referred to in Article 5.1(3) of the Fnvironmental Management Act.

$\Lambda \mathrm{t}$ present, there are no examples of case-law available yet in which a claim based on the premise that water quality standards must hiave an effect on spatial planning has been upheld by the Administrative Law Division of the Council of State. The reason for this seems to be that the Administrative Law Division of the Council of State assumes that the obligations from the Water Framework Directive 
are at this lime not yel concrete and binding to the point where they should be taken into account in the decision making by various public authorities. No actions have yet been based by third interested par ties on the fart that the stand-still principle from the Water Framework Directive is already in force.

\section{Summarizing}

For different waler qualily standards different ways of letting them have effect have been chosen under Dutch law. The quality standards included in the Quality objectives and measurements surface waters Decree can be considered to be limit values, ${ }^{37}$ but only have to be taken into account in the establishment of plans. The quality standards included in the Environmental quality standards dangerous substances surface waters Regulations are valid for all decisions of administrative authorities that may have an impact on surface water quality, but are qualified as guide values. 'l his means that administrative authorities may deviate from these stan dards, provided that such deviations are properly reasoned. There is hardly any case-law yet on the way in which water quality standards impact on spatial plaming decision making. As has been re marked above, no quality standards lor good chemi$\mathrm{cal}$ and ecological status have yet been established to implement the Water Framework Directive.

\section{Effect of European Directives on Dutch spatial planning}

In this section we will examine how the European Direslives, and in particular the Water Framework Directive, may be implemented in Dutch spatial planning. In this, a distinction must be made between standard setting and policy in the field of water quality and that in the field of water quantity. This will be preceded by a brief description of the current Dutch legal system in the field of spatial planning under the Spatial Planning Act presently in lorce and the future system under the new Spatial Planning $\Lambda \mathrm{ct}$.

\section{The legal planning framework: Spatial Planning Act, current and new}

The planning system under the current Spatial Planning ArL is characterized by a strong decen- tralized character. Only the xoning plan can be legally binding upon citizens and only the municipal council is competent to establish zoning plans. In a country where types of use of space are only permitled to the extent that they are permitled by the zoning plan, the system gives a remarkable amount of power to dictate to municipalities. Exactly for this reason certain administrative law correction mechanisms have been included in the Spatial Planning Act from the start, especially the provincial and Ministerial powers to instruct in respect of the zoning plan. In addition the possi bility should be pointed oul of taking what are known as project decisions as an alternative to the zoning plan. These decisions should legally be regarded as decisions to exempt from (parts of) a zoning plan in force.

The repressive powers of supervision in the shape of powers to instruct exist alongside the preventive power to approve of the Provincial Executive ${ }^{32}$ in respect of zoning plans which is very important in administrative practice. In this way we may speak of a monopoly of the municipal council as the establisher of plans that are binding on the citizen, mitigated by the right of veto of the Provincial Fxeculive where the approval of yoning plans is concerned.

The system of the new Spatial Planning Act which has recently been accepted by the Senate and is expected to enter into force in 2008 takes a more pro-active type of steering as its starting point.

What are termed 'structural visions' are established at central, provincial and municipal level. These structural visions must primarily be regarded as indicative policy documents; a legally binding effect is not expressly provided for them.

The main changes under the new Spatial Planning Act however concern the powers fof inter vention) of the higher administrative bodies.

In the first place, the phenomenon of the 'general rules' is introduced, which means that the crown, by means of Orders in Council, and the Provincial Council, by means of provincial bye-laws, may

31 Although the text does not provide complete clarity on this; see thereon the observations at the stat of this sedion.

32 The bodies of the Provincial Executives are responsible for the day-to-day management of the provinces. The bodies of the Provincial Councils are the (indirectly elected) representatives of the poople and also responsible for the gencral management of the provinces. 
establish generally binding provisions which the municipal council has to incorporate in a zoning plan within one year. These general rules moreover immediately after their entry into force and in anticipation of their incorporation in zoning plans acquire direct effect as a mandatory framework for testing in the granting of building permits. The specific powers to instruct remain intact in a slightly altered form.

Both the Minister of Housing, Spatial Planning and the Environment and the Provincial Council are given the power to establish zoning plans in respect of national and provincial interests respectively. This change is of principal importance as this breaks through the monopoly of the municipal council.

The new Spatial Planuing Act also includes rules for both central and provincial projects. A central or provincial project decision has the same legal effect as the current exemption from the zoning plan (under the current Spatial Plamning Act). This means that in future (parts of) a roning plan can also be rendered inoperative by a central or provincial decision in order to enable the realization of a project, possibly under certain conditions.

In contrast to this increase in powers of intervention, there is also, at least for the provincial administration, an important reduction of the power to influence, as the Provincial Executive's power to approve in resped of roning plans is repealed. However, the Provincial Executive retains a considerable remainder of the power to approve because the Provincial executive can issue what is called a 'negative instruction' in the zoning plan procedure against an established moning plan, whereby it can prevent that the (part of) the zoning plan in question enters into force. In this contribution, we will from now on for reality's sake

33 Ispecially the Air Quality Framework Directive (1996/62/FC) and the first Air Quality Daughter Directive $1999 / 30 /[\mathrm{C}$ ).

34 See also: Koelemeijer/Backes/Blom/Bouwman/Hammingh, Consequenties van de EU-luchtkwaliteitsrichtlijnen voor ruimtelijke ontwikkelingsplannen in verschillende EU-landen, Report No. 500052001/2005 and Fijn stof nader bekeken, Report No. 500037005; Flcurke/Koeman, The impact of the ELi Air Quality Standards on the Planning and Authorisation of Large Scale Infrastructure Projects in the >etherlands', JEEPL 2005, p. $375-383$.

35 ABRvS 18 January 2006, No $200507534 / 1$ ADO stadiurn the Hiaguej. take the legal system of the new Spatial Planning $\Lambda c t$ as the starting point, as well as the text of the draft Water Act.

\section{Interlude: European air quality requirements and Dutch Spatial Planning}

Where the quality standards are concerned, there are similarities between the Water Framework Directive and the European Directives in the field of air quality, ${ }^{33}$ especially also where the problems encountered in the implementation are concerned. ${ }^{31}$ In the Netherlands, the standards from the first daughter Directive were initially transposed into the Air Quality Decree from zool, which is secondary implementing legislation under the Environmental Management $\Lambda$ ct. This Decree contained the standards for the maximum allowed amount of $\mathrm{NO}_{2}$ (nitrogen dioxide) and PM 10 (line dust), which slandards should, according to the European Directives, be achieved by 2010. It was provided in the Decree that in the exercise of powers which may have consequences for air quality, administrative bodies have to comply with' the standards included. This means that these standards constituted a hard boundary (limit value) in the use of the powers which were not further differentiated. During a second stage, this system was mitigated somewhat in the $\Lambda$ ir Quality Decree 2005 , in which it was provided that developments that did not lead to a (further) deterioration of air quality, whercby it was morcover possible to make trade-olfs to a certain extent, were allowed. $\Lambda$ second possible relaxation of the rules may be found in the case-law of the highest administrative court, the Administrative Law Division of the Council of Stale, in which it was decided that in all cases 'a real effect' on air quality had to be involved if the standards from the Air Quality Decree were to be applicable. ${ }^{35}$

Nevertheless, it has 10 be concluded that in the Netherlands, as opposed to in some other European countries, the limit values in respect of air quality do not exclusively concern the point sources which result in air pollution, but also the spatial planning decisions which have enabled developments which will factually lead to an increase in emissions. This difference between the Dutch approach and that in other Member States (UK, France, Austria, 
Flanders, Crermany! where concrele decisions are not tested against future limit values $(2010)$ has resulted in the fact that the implementation problem has in a cortain sense occurred prematurely in the Netherlands.

The conclusion to the above has to be that where standards are established, in this case where the permitted emissions are concerned in connection with the desired air quality, whereby it is provided that they 'have to be complied with' these standards in an undifferentiated system of 'administrative powers' constitute a hard legal boundary ('limit val ues'), also in areas where they would not be allowed as a standard. The limitation of permitted emissions of environment-polluting substances after all does not constitute a standard which would be permitted in a (Dutch) zoning plann, as it does not con cern the use of land and buildings and therefore, not spatial planning. By means of the establishment of limit values that 'have to be complied with', the decision to establish (and approve) a zoning plan is also bound by these standards.

The (major) disadvantage that is connected with this, however, is the inflexible and undifferentiated character of the instrument of the limit value. This disadvantage emerges all the more clearly when the limit value is not (only) used in the establishment of plans to combat air pollution, as is the case in many other Furopean Member States, bul (also) in the making of all possible concrete decisions.

A legislative proposal is currently pending in Parliament in which a new system for letting air quality requirements have an effect on spatial planning is proposed. ${ }^{36}$ Generally speaking, the following changes are proposed. The Air Quality Decree 2005 provides that, although limit values must indeed be complied with, an exception applies in case the concentrations in the air of the substance in question as a result of the exercise of those powers (based on spatial planning) improve or at least stay the same and also in case there is a slight increase, due to a measure connected with that exercise or application or due to an effect arising out of that exercise or application and air quality as a whole improves. The Air Quality Act (leg islative proposal) adds two important exceptions, namely that the exercise of the power does not significantly contribute to the violation of a limit value and the exercise of that power fits in with a programme as referred to in the Fnvironmental
Management Act (Article 5.12 in conjunction with Article 5.13). The National Air Quality Cooperation Programme is a national programme to achieve limit values as quickly as possible, to cstablish and implement plans to fulfil newly to be established limit values on time and finally a plan to fulfil the guide values. In this way, the original direct link between air quality requirements and decisions based on the Spatial Planning Act is abandoned and replaced by an indirect link which offers more flexibility. ${ }^{37}$

It remains unclear, however, whether the Euro pean obligations are fully fulfilled under this new system.

\section{Possible effects of water quality and floods security requirements on spatial planning, general}

In the pursuit of the integration of water policy and spatial planning more or less central steering is conceivable. The least invasive form of central steering in the external integration of water and spatial planning takes place by only making use of the structural visions under the draft Water $\Lambda$ ct and Spatial Planning $\Lambda$ ct, the obligation (which already exists under current law) to include a section on water in the explanatory memorandum to spatial planning decisions and making use of administrative consultations. The not legally required 'water test' in accordance with which a section on water is drafted has been characterized ats a policy driven instrument of process which has to ensure that water management interests are already included at the early stages of decision making on spatial planning. The compulsory section on water and the water lest shed light. on water management inlerests, but cannot guarantee that these will not still lose out in the weighing of all spatially relevant interests. The Dutch water test can therefore not be truly compared to the Flemish variation by the

\footnotetext{
36 Kamcrstukkicn II 2006-2007, 30439 .

37 Sec the special issue on air quality of the Tijdschrift voor Milicu en Recht 2006/5 and Hillegers/Lam/Nijmeijer, "Het wetsvoorstel luchtkwalitcit nader beschouwd', Milicu en Recht 2006. pp. 597-605.
} 
same name, which has been included in the Flemish Integrated Water Policy Decree. ${ }^{38}$

The Water Act provides that a national or regional water plan respectively which is to be established by the Ministers involved or the Provincial Council respectively has the status of a central or provincial structural vision as referred to in the new Spatial Planning Act. This option, however, is of only minor importance for the implementation of the Water Framework Directive. $\Lambda$ fter all, the structural vision does not include any standards that are binding upon the citizen or other authorities and (only) fulfils the function of an indicative policy framework. It might however be able to fulfil the function of framework or background to the general rules to be established at provincial level (by means of a bye law or the exercise of other powers based on the new Spatial Planning Act).

The spatial decision that is in the first place relevant in relation to the implementation of European Directives is the zoning plan. After all, this is the only spatial plan that contains standards that are binding on the citizen (concerning the permitted use of space). Initially, only the municipal council is authorized to establish zoning plans. The conclu sion is then that the implementation of the Water Framework Directive as far as the spatial aspects are concerned takes place primarily through the municipality.

However, the new Spatial Planning Acl also introduces the possibility of central and provincial zoning plans. Here, the same applies mutatis mutandis.

In addition to the zoning plan, the power of the provinces and central government to establish gen-

\footnotetext{
38 The Decree of 10 luly 2003 concerning integrated water policy, see thereon: Maeslavrysen (eds.), Integraal waterbeleid in Vlaanderen en Nederland, Die Keure, Brugge 2003, and especially the contribution by De Smedt, Naar een ruimtelijke ordening op waterbasis? De impact van het Vlaamse kaderdecreet van 18 juli 2003 betreffende het integraal waterbeleid op het beleidsdomein van de ruimtelijke ordening, pp. 149-192. See for the Dutch variation in the same publication Van Hall, Water stuurt ruimtelijke inrichting, nieuw denken over oud water, pp. 193-222. See also De Snedt, Watertoets getoesst. Een revolutionair instrument van het decreet van 18 juli 2003 betreffende het integraal waterbeleid', NjW 2004, pp. 902-913 See for a comparison of laws: van Rijswick, 'De watertoets in Vlaanderen en Nederland: Een geschikt instrument voor externe integratie?', in: Lavrysen/Michiels (eds.), Milieurecht in de I age Landen, Rechtsvergelijkende studies over de milieuvergunning, emissiehandel, de watertoets, natuurbescherming en bestuurlijke handhaving in Vlaanderen en Nederland, Boom juridischc uitgevers, Den Haag 2004, [p. 203-213.

39 Kanlersukken II, 2002-2003, 28916, vi, 3, pp. 45-46.
}

eral rules under the new Spatial Planning Art also plays a role in the implementation of standards of international law in national law. By this power, the authorities that are higher ranking than the municipalities may set binding requirements lor - among other things the contents of - spatial decisions of lower authorities. The legislator considers the power of higher ranking authorities than municipalities to establish by or pursuant to Orders in Council or provincial bye-laws generally binding provisions in certain cases to be exceptionally appropriate for the spocdy transposition of $\mathrm{LC}$ Directives and other transnational or FIJ agreements. ${ }^{39}$ The new Spatial Planning $\Lambda$ ct further includes the central project decision and the provincial project decision. In essence, these are exemptions from a zoning plan in force. They therefore only determine that certain standards (in a yoning plan in force) will not apply insofar namely as these standards prevent the realization of a central or provincial project. For this reason, the project decision is not in itself an appropriate means to implement Furopean law rules. It is possible, however, to attach certain regulations (conditions) to a project decision. It is not inconceivable that these regulations could serve to implement the Waler Framework Directive.

\section{Effect of water quality standards on spatial planning}

The contents of a municipal zoning plan may be jointly determined from higher up (by central govcmment and the province). To this end these anthorities that are higher in rank than municipalities have, as was mentioned above, been given two powers of intervention in the new Spatial Planning Act. First of all, the power to issue general rules, namely an Order in Council (by the Crown) and a provincial bye-law (by the Provincial Council). In addition, the specific power to instruct remains intact, which is to be exercised by a Minister /either of Housing, Spatial Planning and the Fnvironment or by another Minister in consultation with the Minister of Housing, Spatial Planning and the Enviromment) or the Provincial Executive respectively. In connection with the required implementation of the Water Framework Directive especially these general rules are eligible for application. It would actually be possible to establish these gener al rules in combination with the Order in Council to 
inslruct and the bye-law to instruct under the Waler $\Lambda$ ct. This option only makes sense and only has added value, however, when the quality requirements under the Water Framework Directive would be 'spatially implemented' or transposed into spatial planning preconditions at national level (in an Order in Council) or at regional level (in a provincial bye law). Possibly, this may be especially impor tant for the category of 'protected areas' under the Water Framework Directive, as particularly for these latter areas a regional transposition may be necessary. The fact is, however, that the general rules can only be established in the interest of 'good, national or regional spatial planning'. This means therefore that the rules must be 'spatially relevant' rules. Purely (environmental or water) quality standards in the technical sense are not spatially relevant. These rules therefore have to be 'translated' into, for example, the way in which the designated use is determined (for example extensive farming with a water buffer zone or with coological valuel or in the terms of use whereby it can be determined that certain types of use are prohibited, unless a licence has been obtained, for example a building permit or prohibition. Although these environmental or water quality standards have spatial planning consequences, they do not of themselves concern spatial planning. Such technical quality standards are therefore unsuitable for inclu sion in a general nule based on the new Spatial Planning $\Lambda$ ct. The above could be considered as a way to provide effect in a moderate supra-local steering scemario. This would exist in a purely bind ing variation if central zoning plans were estab lished in which the quality standards are Iransposed, if this were to be possible.

An alternative means of giving effect to these requirements would be as follows. In the Environ mental Management Act or in an Order in Council pursuant to this Act the quality standards following from the Water Framework Directive can be includcd. It can thereby be provided for which decisions, amongst which the establishment of roning plans, these quality standards have to be complied with. This is the model that was followed in the Dutch implementation of the Air Quality Directives in the Dutch Air Quality Decree, which is an Order in Council based on the Environmental Management Act. In this way it is not opted to 'spatially translate' quality standards, but only to establish precondi tions for later decision making. This legally ensures that these quality standards are (and have to be) followed on penalty of unlawfulness. The advantage of this is clarity and the fact that quality standards do not need to be translated into spatially relevint rules. The disadvantage however is the uncompromising nature of the arrangement.

\section{Effect of the water quantity rules on spatial planning}

In the description of the water assignments in dis tinclion has to be made between salely and llooding, as different standards apply for these aspects. The safety standards have an indirect link with spatial planning, whereas the standards for flooding are directly linked to spatial planning as they are connected with the use of space.

Under the new legislation (the new Spatial Planning Act and the new Water Act) far-reaching reforms have becn made in the way in which steering takes place. For example, the standards for salety and flooding are bindingly established under or pursuant to the Water Act. Direct effect of these standards on spatial planning has not been provided for. The approval of zoning plans and other spatial planning decisions as in force under current law is repealed. In its place, other steering mechanisms are provided, the most important of which are the central and provincial legislative compe tences (based on both the Water $\Lambda$ ct and the new Spatial Planning Act) and the zoning plans at provincial and central level. This more proactive way of steering offers excellent opportunities for realixing the good harmonization of water quantity and spatial planning. As opposed to the ecological quality standards that can be established at provincial level in the provincial environmental bye law, there is no European obligation in force to achieve an end result with respect to water quantity standards. Judging by the text so far of the proposed Flood Risk Marnagement Directive, this Dircetive will not prescribe any legislative standards for salety or flooding either. This considerably increases policy discretion and the flexibility allowed in the use of instruments. As was the case in respect of the relationship between water quality and spatial planning, the different possibilities may range from strong legal binding force and supra-local steering to considerable flexibility, little legal binding force and hardly any supra-local sleering. 


\section{Conclusions: the legal (im)possibilities of harmonization under Dutch law}

The most far-reaching form of harmonization between water and spatial planning may be achieved by including a direct link to spatial planning deci sions in the water legislation for the environmental legislation for the water quality requirements). Here, one should think of a system like the one under the Dutch Enviromental Management Act. This is the system that was initially selected to let air quality requirements have an effect on decision making in the framework of spatial planning. $\Lambda \mathrm{fter}$ all, it cannot be denied that the effect of air quality requirements on spatial planning is strong. In the statulory regulations in which the standard is laid down (for example an Order in Council or a provincial bye-law) it can also be indicated which administrative bodies have to comply with the standards and in the exercise of which powers they have to comply with them. In this way it can be bindingly established that the standards will also apply to decisions in other policy arcas, such as spatial planning. An advantage of this is that standards do not have to be directly relevant for spatial planning or have to be 'translated' first in spatial terms. The competent authority in that calse hals hardly any room left to ignore the standards. In this case too a certain differentiation is possible, whereby the European limits have to be respected where water quality requirements are concerned. It makes a difference, for example, whether the standards have to be complied with or merely taken into consideration. It also makes a difference whether the standards exclusively apply to the establishment of plans or water agreements or to the mak ing of all decisions.

In the case of water quality standards use is made of the system under the Environmental Management Act which well enables an effect with strong binding legal force on other policy areas. This is in fact also necessary, given the European obligations. In the case of standards for safety and flooding, which are of a purdy national law charas: ter and are established on the basis of the Water Act, this type of impact has as yet not been provided for. Standards based on the Water Act only apply to decisions based on that Act. The relationship with spatial planning is only given shape by means of non-binding struclural visions. It does make sense, however, that the choices made in a (provincial) structural vision will be given a further spatial planning interpretation by the province. This is not a certainty, however. Above it has already been remarked that rules for flooding can be used much more easily than spatial planning rules, without any further 'translation' being necessary, than can rules for safely. In both cases the competent authority in the field of spatial planning will have to make an express choice to let safety and flooding standards have an effect on spatial planning.

It may be concluded that it is of the utmost importance that the water quality objectives are (also) based on European directives. This fact establishes certain preconditions for the way in which the harmonization of water and spatial planming should be shaped. It has to be assumed that full flexibility as regards the instruments to use goes against European obligations, especially when the water quality standards are not fulfilled or cannot be fulfilled in the future. From the file on air quality - and particularly from the case-law of the Dutch Council of State - it can be concluded that a certain degree of trading off (as a kind of flexibility and policy discretion) is considered possible, provided limits as to time, place and contents are established for such trading off. Above all it has to be ensured that the European obligations fulfilling the cstablished quality standards - are met (unless the grounds for exemption under the Water Framework Directive are invoked for justified reasons).

In the sccond place, future water management is characterized by an integrated approach which is based on water systems and finds its implementation in the river basin approach. The future Dutch water legislation closely corresponds to this. The cnvisaged water plans which will also be structural visions under the new Spatial Planning AcL ensure the strategic and planning-wise harmonization of water and spatial planning, whereby it has to be kept in mind that these only concern legally nonbinding forms of planning.

Both under the Dutch future water legislation and in the Dutch future spatial planning legislation use is made of different types of stcering instruments. The approval requirements are (largely) repealed and strong pro-active steering mechanisms to be used by the central and provincial authoritics are opted for instead of the familiar repressive steering merhanisms. The provincial 
bye-laws will be playing a crucial role in the realization of water assignments. This is true for the water bye-laws on the basis of the Water Act, the provincial environmental bye laws with cological quality standards (whereby the elfect on other policy areas is also regulated) and for provincial spatial planning bye-laws which offer the province strong possibilities to give full room to water inter ests in spatial planning. All in all, a clear distinction is made between non-binding plans and binding bye-laws. These binding elements under the new legislation may prove to be greatly influential in the field of execulion. Where before the water boards and municipalities were the principal actors, the new supra-local steering mechanisms may relocate executive duties to the provincial or even national level.

Where supra-local interests so require, the possibility is created of making central and provincial zoning plans. Although this possibility initially makes more sense in the achievernent of the water quantity assignment due to the close link with spatial planning, it is also conceivable that the instrument can be used in the realization of the water quality objectives, in particular of good eco logical status.

Whether use is made of the available instruments is not a legal question but a political-administrative one. An important conclusion which may be drawn is that the proposed legal instruments in the legislation that is currently being prepared - the new Spatial Planning Act and the Water Act - in principle make it possible to fulfil the European law water assignments and that there are suitable legal possibilities to give shape to the harmonixation of water and spatial planning with a view to the realization of these water assignments.

\section{Concluding remarks}

An important question dealt with in this article is how standards from water management irrespective of whether they regard water qualily, protection against floods or the prevention of flooding - have to be statutorily laid down so as to be able to have an optimal effect on spatial plan ning. That the relationship between water management and spatial planning is important will not surprise anyone. The effects of climate change will only make this relationship between water management and spatial plamning all the more press ing. However, how these standards can have an effect on spatial planning may differ considerably per Member State. It has become clear from expe riences with requirements under the Air Quality Directives that the Nelherlands initially opted for a very strong - and perhaps overly rigid - impact, also when compared to other Member States. We expect that most Member States have not yet found an answer to the question of how a link may best be established between the standards from water management (as these will follow directly or indirectly from the Water Tramework Directive or the proposal for a Flood Risk Management Directive) and spatial planning. This contribution explains the various possibilities under Dutch law and hopes to initiate a doctrinal debate concerning the question of how 'best' to harmonize (water) quality standards and spatial planning. 